Notes on the Ideology of International Organizations Law : The International Organization for Migration, State-making, and the Market for Migration

Klabbers, Jan

2019-09

Klabbers , J 2019 , ' Notes on the Ideology of International Organizations Law : The International Organization for Migration, State-making, and the Market for Migration ' , Leiden Journal of International Law , vol. 32 , no. 3 , 0922156519000165 , pp. 383-400 . https://doi.org/10.1017/S09?

http://hdl.handle.net/10138/309258

https://doi.org/10.1017/S0922156519000165

unspecified

publishedVersion

Downloaded from Helda, University of Helsinki institutional repository.

This is an electronic reprint of the original article.

This reprint may differ from the original in pagination and typographic detail.

Please cite the original version. 


\title{
Notes on the ideology of international organizations law: The International Organization for Migration, state-making, and the market for migration
}

\author{
Jan Klabbers \\ University of Helsinki, PO Box 4 (Yliopistonkatu 3), 00014 Helsinki, Finland \\ Email: jan.klabbers@helsinki.fi
}

\begin{abstract}
This article discusses the law and practice of the International Organization for Migration (IOM), a littleknown but important international organization. The article aims to illuminate what it is the IOM does; how it influences its member state practices while simultaneously working on member state assignments; and how this affects the dominant theory underpinning the law of international organizations, i.e., the theory of functionalism. The article concludes that the IOM takes functionalist thought to extremes, and in doing so makes visible the latter's ideological nature.
\end{abstract}

Keywords: delegation; functionalism; ideology; International Organization for Migration; privatization

\section{Introduction}

International lawyers pay very little attention to the IOM. This is curious, to say the least: the IOM has a worldwide presence, a hefty budget, and works on a topic that concerns many of us in one way or another. Migration, after all, is a commonplace event, and migrants can be found in all walks of life, from construction workers building football stadia in Qatar to investment bankers in the city of London. Indeed, quite a few academics are migrants as well - including the present author.

The IOM is entrusted with the general task of regulating migration flows, and in doing so exercises a rather overtly political and controversial task. While the regulation of migration flows can be done in a humanitarian spirit, it can also be given effect in a more bureaucratic, managerial spirit, and it would seem that the IOM does a lot of work that its member states are reluctant to do (or to be seen to be doing) themselves.

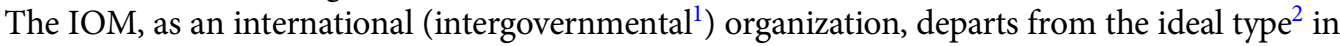
two ways. With Weberian ideal types representing a heuristic device rather than a normatively desirable horizon, the ideal type of international organization is an entity, endowed with several organs and a will of its own, which performs technical tasks (said to be a-political) delegated by its member states, in pursuit of the global common good, and usually at the behest or on behalf of the collective membership. Moreover, this particular ideal type (the ideal type of international organization)

\footnotetext{
${ }^{1}$ I will consistently speak of international organizations, in alignment with standard international legal terminology. These are organizations having states as their members, and therefore need to be distinguished from non-governmental or private organizations.

${ }^{2}$ The notion is borrowed from Weber to suggest that there is a model which may exist in theory but may not often (and possibly never) be fully met in practice. Weber himself suggests, with respect to ideal types of economic actors, that these are usually 'unrealistic or abstract in that they always ask what course of action would take place if it were purely rational and oriented to economic ends alone'. See G. Roth and C. Wittich, Max Weber, Economy and Society (2013), Vol. I, 18-22.
} 
presupposes a uni-directional line of influence: member states are considered to control the organization, not the other way around, although on occasion an organization may hold a member state to account if that state ignores agreed-upon rules. ${ }^{3}$ The point to grasp is that the veracity of these considerations is not thought to be particularly relevant: whether the direction of influence in reality is uni-directional is not all that important; what matters for the ideal type is that generations of international lawyers have created such a type trough their writings, reflections and even judicial decisions. ${ }^{4}$ The sort of entity people have in mind when they talk about international organizations include examples such as the World Health Organization, devoted to global public health, or the World Meteorological Organization, dedicated to understanding weather patterns with a view to making the world safe from hurricanes, typhoons, floods and the like, or even the multi-functional United Nations, thought of as the harbinger of global peace and welfare.

The IOM does not live up to this ideal type in two fundamental ways. First, it can be said to do some of the 'dirty work' of states, at a larger scale than applies to most other international organizations and in ways that do not apply to most other international organizations, often commissioned by individual member states. At the same time, it lacks the association with the global public good that so characterizes the ideal type. The IOM is probably not alone in this (many regional organizations ${ }^{5}$ or product-based international organizations ${ }^{6}$ cannot be said to embody the global public good either, no matter how the latter is defined), but among organizations of near-universal scope, the IOM nonetheless stands out.

Second, the IOM actually does influence, and aspires to influence, the policies and practices of its member states to a considerable extent. Again, it is not alone in this: much the same can be said about many international organizations. Again though, the IOM stands out, in that it has a very specific mandate to this end, a mandate that is specifically fashioned so as to stimulate tailor-made solutions rather than generic policy guidelines - a non-regulatory mandate. The question that arises then is to what extent and how solutions devised for one member state can nonetheless have a radiating effect on other member states. To be sure, these are matters of degree: many organizations aspire to influence member state policies; it is just that the IOM does so in greater depth than others, and without having been granted a general regulatory power.

The above two issues (the IOM doing the work of its member states, and at the same time influencing the policies and practices of its member states) will be central to this article, as they expose the Achilles' heel of functionalism. The IOM, as an organization, is dependent on fees for its activities and expertise - more so than most other international organizations. Fortunately for the IOM, then, there is a market for it to operate on, and it does so with considerable success. This market for migration forms the backdrop to discussions of what the IOM is and does. The functioning of the IOM therewith can be expected to owe far more to the private sector than the theory of functionalism, emphasizing the global public good, can handle.

A prominent international lawyer once suggested that the role of international organizations

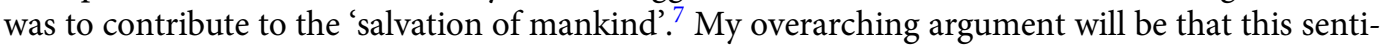
ment provides the beginning of the answer to puzzlement about the role of the IOM: the soundbite 'salvation of mankind' nicely captures the core attraction of functionalism. Legal rules are inevitably based on underlying theories, however tacit these may remain: the rule (for instance) that international organizations are entitled to certain privileges and immunities can be traced back to the theory of functionalism. Functionalism in turn suggests that international organizations

\footnotetext{
${ }^{3}$ An early comprehensive formulation is P. S. Reinsch, Public International Unions; Their Work and Organization: A Study in International Administrative Law (1911); the leading recent statement is H. G. Schermers and N. Blokker, International Institutional Law: Unity within Diversity (2018).

${ }^{4}$ For an overview of this development see J. Klabbers, 'The EJIL Foreword: The Transformation of International Organizations Law', (2015) 26 EJIL 9.

${ }^{5}$ Think of the European Union, or the Organization of Islamic Cooperation.

${ }^{6}$ Think of the Organization of Petroleum Exporting Countries, or the International Olive Council.

${ }^{7}$ N. Singh, Termination of Membership of International Organisations (1958), vii.
} 
generally perform specific functions in the service of the common good and their work, thus, ought to be facilitated - the 'salvation of mankind' may be at stake. And this, in turn, derives strength from a layer of underlying assumptions, such as that co-operation between states is itself commendable, that law and politics are best kept separate, that certain means can help achieve certain ends, etc. The ambition of this article is to suggest that the second element is sometimes questionable: the IOM represents a hard case for the theory of functionalism, precisely because its activities seem less geared to the public good (however precisely defined) than one could legitimately expect, and instead seem to serve the individual interests of individual member states. And if this second element is questionable, the connection between the background assumptions ('co-operation is good', e.g.) and the legal rules themselves, is broken, perhaps irreparably so.

The theory of functionalism, it will turn out, has a hard time explaining why the work of the IOM ought to be facilitated; instead, closer study of the work of the IOM and its legal setting indicates that functionalism is best seen not as theory, but as ideology: a more or less coherent set of thoughts with little explanatory power but strong normative appeal, and working so as to legitimize the use of power. Such an understanding of functionalism as ideology will help to explain both how the IOM can do a lot of the not-so-pleasant work of states without attracting much opprobrium, and how it can influence those same member states in their practices relating to migration and border management.

The main purpose of this article is to examine the practices of the IOM in light of the functionalist theory of international organizations law, and in order to enhance the understanding of functionalism. In other words: I aim to sketch what the IOM is and what it does, and analyse what this means for functionalism. The setting is complicated: it involves an international organization (with accompanying legal status and privileges), operating as a state apparatus on a private market and doing so for profit. The interest of this article resides predominantly in discussing how this situation is facilitated by, and in turn affects, the theory underlying international organizations law. ${ }^{8}$

Section 2 discusses the market for migration, the backdrop against which much of the work of the IOM must be seen. Section 3 will discuss the history of the IOM and its constitution, while Section 4 goes into several aspects of the work of the IOM: both combine description with analysis, and sketch a comprehensive picture of how the legal framework facilitates and influences the IOM's operational activities. In Section 5 the IOM will be connected to functionalist thought, while Section 6 concludes.

\subsection{The market for migration}

Migration is a highly ambivalent notion. On the one hand, it taps into public order sentiments, into thoughts and feelings about national security, the continuation of social security services, etc. This often generates a drive to limit migration. On the other hand, migration is also thought to 'be a source of prosperity, innovation and sustainable development', as the Global Compact for Safe, Orderly and Regular Migration, published in 2018, puts it. ${ }^{9}$ The same tension between open and closed borders, welcoming and repelling approaches to migration, is visible in other legal instruments on migration, including the 1990 International Convention on the Protection of the Rights of all Migrant Workers and Members of their Families ${ }^{10}$ and reports such as the 2017 report of the United Nations Special Rapporteur on the Human Rights of Migrants, which underlines that 'migrants are drivers and enablers of development, contributing to economic growth wherever they go', while simultaneously recognizing 'a strong need to regulate mobility'. ${ }^{11}$

\footnotetext{
${ }^{8}$ Further study of the assumptions underlying functionalism will have to wait for a different occasion.

${ }^{9}$ This Global Compact is negotiated under auspices of the United Nations; the words cited can be found in point 8 . See UN Doc. A/RES/73/195.

${ }^{10} 1990$ International Convention on the Protection of the Rights of all Migrant Workers and Members of their Families, 2220 UNTS 3948, Art. 79.

${ }^{11}$ See UN Doc. A/HRC/35/25 (2017), paras. 25 and 17 respectively. Note that the special rapporteur advocates the regulation of mobility rather than the imposition of restrictions.
} 
The IOM Constitution heralds the contribution migrants can make to economic life, but nonetheless affirms that states remain in control of the numbers and standards relating to admission: these matters remain within the 'domestic jurisdiction' of the IOM's member states. ${ }^{12}$

Some migrant labour, the skilled kind, is often considered highly desirable from a public policy perspective: think of doctors and nurses, but in the abstract, it is difficult to distinguish between poor, unskilled labourers and highly qualified professionals with unique skill sets. What is more, even unskilled labourers may, on occasion, be highly desirable. Flexible production demands not just that the highly skilled can move across borders, but the same applies to industry workers. ${ }^{13}$ Hence, sometimes unskilled labour is banned, at other times it is most welcome. As a result, states draw up detailed legislation trying to distinguish between these categories of migrants, as well as the situations in which they are either welcome or not, the result being the creation of a market for legal and other migration services, e.g., related to smoothing migration procedures. ${ }^{14}$

This ties in with some of the more notorious problems associated with migration. The closing of borders forces people to 'go underground': where the formal, state-run procedures and mechanisms hermetically close off countries, it is only to be expected that an underground circuit emerges, inhabited by human smugglers and traffickers willing to take great risks (imprisonment, getting shot at, drowning), often crossing choppy waters at night and at high speed in unseaworthy vessels, or trekking through deserts and mountain areas with little food or shelter. ${ }^{15}$ In other words, a grey market is created where people can make a living from activities such as forging identity papers or helping others, for a fee, to cross borders. ${ }^{16}$ This market is constantly changing; its actors need to be very agile, alert and adaptable. ${ }^{17}$ A single state might not be able to keep up with, let alone anticipate, new techniques developed on the market for migration. ${ }^{18}$ This, in turn, generates a demand for specific products and services, and the IOM, with its diverse experiences in a wide variety of settings, might be able to meet the agility and adaptability of the market actors - and might be better able to do so better than most governments, ${ }^{19}$ and perhaps at lower prices too. ${ }^{20}$

Involving the IOM aligns with both the national security dimension of migration and the way migration often works in practice, and ties in with at least two prominent trends: the outsourcing

\footnotetext{
${ }^{12}$ Constitution of the International Organization for Migration, Art. 1(3), available at www.iom.int/constitution (accessed 3 February 2018).

${ }^{13}$ A. Ong, Neoliberalism as Exception: Mutations in Citizenship and Sovereignty (2006), 125.

${ }^{14}$ Players on this market include global consultancy firms. See, e.g., www2.deloitte.com/global/en/pages/legal/solutions/ mobility-immigration.html (accessed 3 February 2018); www.pwc.com/ca/en/law/immigration-law/global-immigration. html (accessed 3 February 2018).

${ }^{15}$ The UN special rapporteur on the human rights of migrants, Francois Crépeau, reaches a similar conclusion; see UN Doc. A/HRC/35/25 (2017), para. 30.

${ }^{16}$ As Koslowski summarizes: 'If all countries had "open border" policies toward migration and none had laws limiting the number of migrants and requiring them to enter through official ports of entry, there would be no such thing as "illegal" migration, and no one would need to pay smugglers to cross a border.' See R. Koslowski, 'Immigration, Crime, and Terrorism', in M. R. Rosenblum and D. J. Tichenor (eds.), Oxford Handbook of The Politics of International Migration (2012), 511-31.

${ }^{17}$ See generally J. Harding, Border Vigils: Keeping Migrants Out of the Rich World (2012).

${ }^{18}$ Guilfoyle conceives of people-smuggling as 'often a flexible, entrepreneurial activity' and juxtaposes this with monopolistic criminal organizations - the latter may be too set in their ways to be very successful, so the implicit suggestion runs. See D. Guilfoyle, Shipping Interdiction and the Law of the Sea (2009), at 183. Others hold that states often lack the power to impose conditions for immigration on their own: see K. Newland, 'The Governance of International Migration: Mechanisms, Processes, and Institutions', (2010) 16 Global Governance 331, at 342 (approvingly quoting Pechoud and de Guchteneire).

${ }^{19}$ Cooley issues a general word of caution, noting that governance based on contracting of services and activities tends to diminish governance outcomes and may have important, and often unintended, transformative consequences for the roles, priorities, and even legitimacy of governors'. See A. Cooley, 'Outsourcing Authority: How Project Contracts Transform Global Governance Networks', in D. D. Avant, M. Finnemore and S. K. Sell (eds.), Who Governs the Globe? (2010), 238.

${ }^{20}$ Political geographers point out that border management, under New Public Management mantras, is expected to be profitable, or at least cost-effective. See, e.g., E. K. Prokkola, 'Technologies of Border Management: Performances and Calculation of Finnish/Schengen Border Security', (2013) 18 Geopolitics 77.
} 
of public tasks by governments, and the practical re-location of border crossings. First, the existence of private military companies and privatized prisons suggests that government functions are more often outsourced, even in matters related to (national) security, with one of the advantages for those governments being that while they continue to exercise control, this control becomes indirect, exercised as it is through agents; therewith it becomes more difficult to hold governments accountable. ${ }^{21}$ Establishing a principal-agent relationship always shifts some of the responsibility for proper behaviour to the agent. ${ }^{22}$ Doing so makes decisions more difficult to trace and hides from view the political authority behind decisions, tapping into what public administration scholars refer to as the problem of the 'many hands'. ${ }^{23}$

And yet, the member states of the IOM remain firmly in command, in particular when individually hiring the IOM's services. In such a setting, the IOM operates like a private contractor, albeit one of public status. ${ }^{24}$ The agent will have some discretion, but will largely need to operate according to instructions, and the legal text of the IOM Constitution makes this possible, with its references to working for the member states and its limited references to humanitarianism; indeed, the IOM pictures itself as 'supporting' member states - a useful tactic which may help to deflect attribution of responsibility if and when necessary. ${ }^{25}$ The IOM points this out when advertising its services: its border management activities are designed as partnerships, with the requesting government and other interlocutors working closely with the IBM Team to identify needs, determine priority areas, and shape and deliver interventions' ${ }^{26}$ It also notes that it engages in partnerships with the private sector: so-called Visa Application Centre services have been developed for member states (such as Canada), together with the private company VFS Global. ${ }^{27}$ VFS Global, in turn, headquartered in Dubai, sells security - this is what its website discloses under the heading 'our expertise'. ${ }^{28}$ Its concept of security involves such things as fraud and criminal investigations; it is less obvious that it provides individuals with security against overzealous governments.

Moreover, the IOM is an attractive partner due to its repository of diversified practical experiences, with staff having been deployed in a variety of settings and thus having learned how to operate and manage a wide range of activities in different sets of circumstances. It boasts the capacity 'to meet new migration challenges on the national, regional and international levels'. ${ }^{29}$

This aligns with a second trend: the trend to move the border posts as much forward as possible. ${ }^{30}$ It has been reported, e.g., that the EU offered Gaddafi's Libya $€ 20$ million for accommodation centres and another $€ 60$ million for what was termed 'migration management' in $2009 .{ }^{31}$ In other

\footnotetext{
${ }^{21}$ See generally P. Verkuil, Outsourcing Sovereignty: Why Privatization of Government Functions Threatens Democracy and What We Can Do about it (2007).

${ }^{22}$ This is, one may surmise, one of the benefits of delegation (at least for the authorities doing the delegating), but not usually recognized as such in the rationalist literature. See, e.g., D. G. Hawkins et al., 'Delegation under Anarchy: States, International Organizations, and Principal-Agent Theory', in D. G. Hawkins et al. (eds.), Delegation and Agency in International Organizations (2006), 3 (listing, amongst others, the management of policy externalities, the facilitation of collective decision-making and enhancement of credibility as benefits of delegation).

${ }^{23}$ See M. Bovens, The Quest for Responsibility: Accountability and Citizenship in Complex Organizations (1998).

${ }^{24}$ Ashutosh and Mountz do not mince their words: '... governments contractually employ the IOM to carry out a range of migration-related services that governments find themselves unable or unwilling to carry out for legal and political purposes'. See I. Ashutosh and A. Mount, 'Migration Management for the Benefit of Whom? Interrogating the Work of the International Organization for Migration', (2011) 15 Citizenship Studies 21.

${ }^{25}$ www.iom.int/immigration-and-border-management (accessed 30 August 2017).

${ }^{26} \mathrm{Ibid}$. IBM, incidentally, stands for Immigration and Border Management.

${ }^{27}$ See Immigration and Border Management Annual Review 2012 (2013), at 5.

${ }^{28}$ www.vfsglobal.com/our_expertise/security_practices.asp (accessed 13 September 2017).

${ }^{29}$ See supra note 25 .

${ }^{30}$ See generally the fine study by T. Gammeltoft-Hansen, Access to Asylum: International Refugee Law and the Globalisation of Migration Control (2011).

${ }^{31}$ Harding, supra note 17 , at 80.
} 
words: Libya would come to be an outpost for the EU. ${ }^{32}$ And the fall of Gaddafi has done little to stop the basic idea: reportedly, Italy concluded a memorandum of understanding in 2012 with the new regime. ${ }^{33}$ By the same token, and better known since the Tampa incident of 2001 (briefly discussed below), Australia has financed border processing operations in both Indonesia and Papua New Guinea, usually involving the IOM as well ${ }^{34}$, and McNevin concludes there is little doubt 'that such schemes are designed to prevent asylum seekers from claiming asylum on Australian territory and under Australian law ${ }^{35}$ States are unlikely to allow migration officials of other states to exercise formal authority on their territories, but might be far more willing to allow IOM officials on their territories. ${ }^{36}$

In this market for migration, the IOM has a strong claim to being seen (and is often recognized $^{37}$ ) as an expert body, able to tap into a wide diversity of experiences and offering a wide range of services. ${ }^{38}$ Hence, the drive towards privatization and the tendency to move border posts forward both conspire to create a specific role for the IOM, a role facilitated by its constitution, espousing a combination of managerial and humanitarian missions. For that is of course the other side of the coin: even if the IOM lacks a rights-based protection mandate, as an international organization it is expected to observe basic principles of humanity in ways that do not always (even if they should) apply to local law-enforcement agents. ${ }^{39}$ Faced with the choice of being processed by an IOM representative or a local authority, perhaps someone like the notorious Arizona sheriff Joe Arpaio, few would opt for the latter. ${ }^{40}$ The IOM can (and does) tap into the language of human rights and humanitarianism, and as such can position itself as an irresistible partner for states. Ashutosh and Mount observe that 'the IOM strategically synthesizes the language of international humanitarianism and equally prevalent discourses of national security. ${ }^{41}$ This leads them to the conclusion that the IOM 'functions as a state apparatus in supranational guise'. ${ }^{42}$ In addition, it is a defining feature of the IOM that, as a public actor, it operates on what is largely a private market: the market for migration products and services.

\footnotetext{
${ }^{32}$ Additional EU alternatives (the European Agenda on Migration, the so-called Khartoum Process) are briefly discussed in C. Ferstman, International Organizations and the Fight for Accountability: The Remedies and Reparations Gap (2017), 37.

${ }^{33}$ Harding, supra note 17 , at 80

${ }^{34}$ See also A. Hirsch and C. Doig, 'Outsourcing Control: The International Organization for Migration in Indonesia', (2018) 22 International Journal of Human Rights 681. In 2016, news broke of all sorts of human rights related issues in these centres, but without there being mention of the IOM: see P. Farrell, N. Evershed and H. Davidson, 'Australia's Detention Horror', Guardian Weekly, 10 August 2016, available at www.theguardian.com/australia-news/2016/aug/10/the-nauru-files2000-leaked-reports-reveal-scale-of-abuse-of-children-in-australian-offshore-detention (accessed 8 April 2019).

${ }^{35}$ See A. McNevin, 'Forced Migration in Australia, New Zealand and the Pacific', in E. Fiddian-Qasmiyeh et al. (eds.), Refugee and Forced Migration Studies (2014), 639, at 644.

${ }^{36}$ Moreover, since the 1980 s, airlines have been tasked with immigration control on airports and terminals far from their destinations, operating as de facto immigration officials. See S. Scholten and A. Terlouw, 'Private Carriers as Experts in Immigration Control', in M. Ambrus et al. (eds.), The Role of 'Experts' in International and European Decision-Making Processes: Advisors, Decision Makers or Irrelevant Actors? (2014), 288.

${ }^{37}$ See, e.g., M. Bradley, 'The International Organization for Migration (IOM): Gaining Power in the Forced Migration Regime', (2017) 33 Refuge 97.

${ }^{38}$ Antecedent thinking can be traced back to F. B. Sayre, Experiments in International Administration (1919), who merrily characterized joint ventures between states to protect certain particular, private interests as examples of international organizations.

${ }^{39}$ The power of international organizations is often held to rest in part on their legitimacy, and this, in turn, owes something to how they behave. Among the leading studies on legitimacy and international organizations, concentrating on the UN Security Council, is I. Hurd, After Anarchy: Legitimacy and Power in the United Nations Security Council (2007).

${ }^{40}$ Some of Arpaio's antics are sketched in Harding, Border Vigils, 108-18. Arpaio would gain further notoriety when he was pardoned by US President Trump in 2017: D. Smith, 'Donald Trump defends controversial pardon of "patriot" Joe Arpaio', Guardian, 28 August 2017, available at www.theguardian.com/us-news/2017/aug/28/donald-trump-defends-joe-arpaiopardon-patriot (accessed 13 September 2017).

${ }^{41}$ Ashutosh and Mount, supra note 24 , at 27.

${ }^{42}$ Ibid., at 34 .
} 


\section{The IOM: A brief guide}

The IOM must be one of the most curious international organizations ever created, so much so that international lawyers have little idea how to pigeonhole it - if they think of the IOM at all. The IOM is rarely mentioned in big bulky handbooks on human rights or migration (migrant rights and human rights are largely kept separate) ${ }^{43}$ and if mentioned at all, this serves usually merely to confirm that the IOM exists. ${ }^{44}$ The scarcity of attention for the IOM suggests that there is something about the IOM that keeps observers at bay - perhaps it is no coincidence that entire monographs can be written on migration and global justice or the human rights of migrants without even once referring to IOM, ${ }^{45}$ and that a rich and subtle critical monograph on law and migration hardly mentions the IOM either. ${ }^{46}$

Neither does the IOM figure much in the handbooks on international organizations. It has its own brief entry in Reinalda's invaluable history of international organizations, ${ }^{47}$ but is not mentioned in most others, ${ }^{48}$ although it is referred to a few times in the even more recent Oxford Handbook of International Organizations. ${ }^{49}$ In fact, the confusion surrounding the IOM is well-captured in Chantal Thomas's claim that the IOM is 'not a treaty-based organization' but rather an 'agency established by governments'. ${ }^{50}$ The IOM, in fact (and like international organizations generally), is both, if only because the distinction drawn by Thomas is legally unpersuasive: the IOM is a treaty-based organization, doing things for the governments that created it.

The neglect and confusion surrounding the IOM is cause for some surprise: with 166 member states and an annual budget of some US\$ two billion, a head office, two administrative offices, nine regional offices and two liaison offices and some 9,000 operational staff spread over the globe, the IOM is by no means to be considered as a small or negligible entity. ${ }^{51}$

Perhaps one of the reasons why so little is known about the IOM resides in the circumstance that it is not particularly transparent. Some of the information on its website is hidden behind a password (understandably so perhaps, as it relates to documents for the plenary meeting of the IOM Council), and other bits and pieces are simply absent. While one can find out who the current director-general is (a Portuguese politician named António Vitorino), there is no information regarding his predecessors, nor is there any information available about other leading officials: it remains unclear who the IOM's legal counsel is, for instance.

The history of IOM goes back to 1951, after an attempt to set up a Migration Administration within the International Labour Organization (ILO) had come to naught due in particular to US resistance: the USA worried that such a migration administration within the ILO might come to

\footnotetext{
${ }^{43}$ See D. Shelton (ed.), The Oxford Handbook of International Human Rights Law (2013).

${ }^{44}$ See Rosenblum and Tichenor, supra note 16; V. Chetail and C. Bauloz, Research Handbook on International law and Migration (2014); E. Fiddian-Qasmiyeh et al. (eds.), The Oxford Handbook of Refugee and Forced Migration Studies (2014).

${ }^{45}$ See S. S. Juss, International Migration and Global Justice (2006); V. Chetail, 'The Human Rights of Migrants in General International Law: From Minimum Standards to Fundamental Rights', (2013) 28 Georgetown Immigration Law Journal 225.

${ }^{46}$ See C. Dauvergne, Making People Illegal: What Globalization Means for Migration and Law (2008).

${ }^{47}$ See B. Reinalda, Routledge History of International Organizations: From 1815 to the Present Day (2009), 352.

${ }^{48}$ See Schermers and Blokker, supra note 3; P. Sands and P. Klein, Bowett's Law of International Institutions (2009); C. F. Amerasinghe, Principles of the Institutional Law of International Organizations (2005); S. Cassese (ed.), Research Handbook on Global Administrative Law (2016). The IOM gets some mentions in the work of Klabbers, but not too much either. See, e.g., J. Klabbers, An Advanced Introduction to the Law of International Organizations (2015), 14, at 115.

${ }^{49}$ Ironically, the IoM more deeply discussed in that volume is the Institute of Medicine (IoM), affiliated with the US National Academy of Science and by no means to be considered an international organization. See M. Koenig-Archibugi, 'Accountability', in J. K. Cogan, I. Hurd and I. Johnstone (eds.), The Oxford Handbook of International Organizations Law (2016), 1146, at 1158-9.

${ }^{50}$ See C. Thomas, 'Transnational Migration, Globalization, and Governance: Theorizing a Crisis', in A. Orford and F. Hoffmann (eds.), The Oxford Handbook of the Theory of International Law (2016), 882, at 899.

${ }^{51}$ See www.iom.int/files/live/sites/iom/files/about-iom/docs/iom_snap_en.pdf (accessed 16 September 2017).
} 
undermine domestic decision-making prerogatives regarding migration, ${ }^{52}$ and was concerned about the communist member states of the ILO and their insistence on mandatory repatriation of Eastern Europeans. ${ }^{53}$ Still, within Europe many people were on the move, and the messy situation concerning migration in Europe after the Second World War spurred the creation of the Provisional Intergovernmental Committee for the Movement of Migrants from Europe (PICMME): non-permanent and outside the UN family (never mind the ILO system), but something of an agency nevertheless. ${ }^{54}$ Provisional as this was, a year later it was transformed into the Intergovernmental Committee for Migration in Europe (ICEM), with two further transmogrifications in its future: ICEM became the Intergovernmental Committee for Migration in 1980, and in 1989 finally became the International Organization for Migration. ${ }^{55}$

These changes in the name are suggestive: an 'intergovernmental committee' is, generally, a fairly loose entity, doing what governments tell it to do and nothing more. ${ }^{56}$ The term 'international organization' by contrast, comes with different associations, and suggests an entity that may have been created by states but nonetheless can claim some independence or autonomy, if only (or precisely) in order properly to perform the functions set by the member states. In other words, the name may reflect the degree of direction given by the member states but, importantly, does not reflect what kind of tasks the entity is asked to perform. Then again, there is generally a tension between these two prisms: that of autonomy, and that of dependence, ${ }^{57}$ and the former legal adviser to IOM's predecessor captures the tension well when noting that the revamped IOM offers an 'excellent tool', but nonetheless 'only a tool, and governments are free to decide to which extent they want to use this tool'. 58

The position of the IOM was further solidified when in 2016 it joined the UN family, a group of some 20 international organizations closely related to and co-operating with the United Nations. This cemented a working relationship between the UN and the IOM going back to the 1990s. Some observers expect at least some teething problems; while they acknowledge that IOM has worked hard to overcome its image as a tool in the hands of western member states, nonetheless the organizational cultures are distinct: if the UN at large (and UNHCR in particular) is used to holding states to account, the IOM often acts on behalf of states. Its projects, as well-placed observers suggest, 'reflect individual member state's interests'. ${ }^{59}$

This is hardly a novel development. One of the most striking features of the organization prior to the 1990s is the complete absence of member states from Eastern Europe indicating that the IOM played a role as an instrument of Cold War politics and never owed much to humanitarian considerations alone.

The functions and purposes of the IOM are, to some extent, fairly typical of those of international organizations generally. Article 1 of the IOM Constitution specifies in paragraph 1(e) that IOM shall be a platform for discussion between member states, and paragraph 2 of the same

\footnotetext{
${ }^{52}$ See R. Perruchoud, 'From the Intergovernmental Committee for European Migration to the International Organization for Migration', (1989) 1 International Journal of Refugee Law 501, at 503.

${ }^{53}$ See M. Ducasse-Rogier, The International Organization for Migration 1951-2001 (2001), 15.

${ }^{54}$ For a useful discussion of the creation of PICMME see R. Karatani, 'How History Separated Refugee and Migrant Regimes: In Search of their Institutional Origins', (2005) 17 International Journal of Refugee Law 517.

${ }^{55}$ See generally also J. Elie, 'The Historical Roots of Cooperation between the UN High Commissioner for Refugees and the International Organization for Migration', (2010) 16 Global Governance 345.

${ }^{56}$ Indeed, the drafting history reveals that the member states opted for something 'intergovernmental' on purpose, in the mistaken belief that this would somehow be less of an abdication of sovereignty than creating an 'international' entity. See Karatani, supra note 54, at 537.

${ }^{57}$ See, e.g., J. Klabbers, 'Two Concepts of International Organization', (2005) 2 International Organizations Law Review 277.

${ }^{58}$ See Perruchoud, supra note 52, at 516.

${ }^{59}$ See N. R. Micinski and T. G. Weiss, 'International Organization for Migration and the UN System: A Missed Opportunity', available at www.futureun.org/media/archive1/briefings/FUNDS_Brief42_IOM_UN_Migraton_Sept2016.pdf (accessed 13 September 2017). See also, critically, E. Guild, S. Grant and K. Groenendijk, 'IOM and the UN: Unfinished Business', Queen Mary Legal Studies Research Paper No. 255/2017.
} 
Article, again fairly typical, suggests that the IOM shall co-operate with other organizations active in the field. Yet, whereas with other organizations the purposes and functions often read like a vaguely cosmopolitan tract, the IOM Constitution quickly gets down to business, and it is worth noting that the IOM Constitution does not mention a rights-based protection mandate. Indeed, this is widely seen as problematic: the UN Special Rapporteur on the Human Rights of Migrants, in his 2013 report to the UN General Assembly, stated in no uncertain terms that the mandate of IOM would need to be fundamentally revised before it could be seen as a proper humanitarian agency and, even stronger still, the IOM should cease some of its activities (in particular relating to the operation of detention centres), as these are considered to be against human rights law and the UN Charter. ${ }^{60}$

The very first preambular recital of the IOM Constitution mentions that the provision of migration services at an international level is often required to ensure the orderly flow of migration movements throughout the world', and Article 1 starts by tasking the organization with the 'organized transfer' of migrants, refugees, displaced persons, and others. Paragraph 1(c) goes a step further still, and orders the organization to provide, at the request of any member state, an entire list of specific migration services having to do with the controlling of streams of migrants, including such things as processing, recruitment, medical examination, and selection. It is this paragraph in particular which pictures the IOM as a service provider for its member states, and not particularly concerned with any conception of cosmopolitan idealism. Indeed, as noted above, Article 1, paragraph 3 takes a step back from cosmopolitanism, and specifically holds that both the control of standards of admission concerning migrants and the number of migrants to be admitted both remain within the domestic jurisdiction of states.

The financing of the IOM likewise confirms that the IOM was set up as an agency to provide specific services. The Constitution distinguishes, in Article 20, between the administrative and the operational costs of the organization; the former are subject to a regular membership fee, the latter are to be paid on a voluntary basis and may even have strings attached, in that Article 20, paragraph 3 specifies that any voluntary contributor can set terms and conditions - the only requirement is that these must be consistent with the functions and purposes of IOM. Moreover, Article 20 , paragraph 4 , describes what is meant by administrative costs, and explicitly excludes any costs made in connection with the services to be provided under Article 1(c); ${ }^{61}$ precisely those related to migrant processing, medical examination, screening, etc. In other words, the IOM is forced to enter the market for migration if it wishes to survive in a meaningful way, ${ }^{62}$ and its entrepreneurial characteristics are regularly highlighted in the literature. ${ }^{63}$

The Constitution merely envisages the IOM to have two organs: a Council, in which all member states are represented, and an administrative body referred to as the Administration. The Constitution makes no mention of a Standing Committee on Programmes and Finance, yet such an organ is in existence (since 2007, it seems ${ }^{64}$ ). It is open to all member states (but chances are that not all are actually represented) and envisaged, it seems, as something of a subsidiary executive organ: among its tasks is to take urgent decisions when the Council is not in session, subject to later approval by the Council. ${ }^{65}$

\footnotetext{
${ }^{60}$ See UN Doc. A/68/283 (2013), paras. 112, 113. Note that none of these concerns was decisively addressed when the IOM joined the UN family, although the relevant agreement stipulates that the IOM 'undertakes to conduct its activities' in accordance with the UN Charter and other relevant legal instruments. The text is contained in UN Doc. A/70/976 (2016).

${ }^{61}$ To be sure, the provision also refers to Art. 1(d), which essentially addresses the other side of the coin: return migration, including voluntary repatriation.

${ }^{62}$ In 2013 , the UN special rapporteur on the human rights of migrants noted that more than $97 \%$ (!) of the IOM budget came from sources other than compulsory membership fees, leading him to conclude that 'the donor states have a large role in determining the organization's work and priorities'. See UN Doc. A/68/283 (2013), para. 114.

${ }^{63}$ See, e.g., Bradley, supra note 37; Hirsch and Doig, supra note 34.

${ }^{64}$ Its rules of procedure were adopted by the Council in 2007, as were its terms of reference. Both were amended in 2013. Note again how opaque the available information is.

${ }^{65}$ Constitution of the International Organization for Migration, Art. 10 gives the Council the authority to set up such subsidiary bodies as 'may be required for the proper discharge of its functions'.
} 
Administratively, the IOM is organized in four departments. The humanitarian branch is the Department of Operations and Emergencies, through which IOM responds to crisis situations. Here, humanitarian ideals are foregrounded through four separate divisions and one unit, engaged in activities ranging from information gathering to post-crisis repatriation. The departments mostly focused on organizational matters are the Department of International Cooperation and Partnerships, and the Department of Resources Management. Through a number of divisions and units, these are engaged in migration research, relations with donors and other partners, media and communication, staff travel co-ordination, accounting, human resources, and related activities. They mostly resemble the central administration of any public institution, with their tasks mutatis mutandis being not all that different from those of, say, the central administration of most universities.

For present purposes, however, it is the IOM's fourth department that may be considered most interesting: the Department of Migration Management. This is divided into five divisions and a single unit, carrying responsibility for migration health, labour migration, and border management. It is here that IOM provides regularized services to its member states, and indeed, the language used on its website closely mimics the language of consultancy firms. It is noted for instance that, ' $[w]$ hen properly managed, labour migration has far-reaching potential for the migrants, their communities, the countries of origin and destination, and for employers' ${ }^{66}$ In this setting, 'IOM strives to protect migrant workers and to optimize the benefits of labour migration for both the country of origin and destination as well as for the migrants themselves'. ${ }^{67}$ And under the heading of 'objectives', the IOM suggests, with respect to labour migration, that it can offer 'policy and technical advice to national governments', support structures that promote 'efficient, effective and transparent labour migration flows', assist governments in promoting 'safe labour migration practices', facilitate the 'recruitment of workers', and promote the 'integration of labour migrants in their new workplace and society'. ${ }^{6}$

The same Department is responsible for the IOM's work on counter-trafficking and for arranging voluntary return and reintegration of migrants. ${ }^{69}$ On counter-trafficking, it offers capacity building of governmental and civil society institutions and technical support, while also offering direct assistance to victims of trafficking, engaging in research, and maintaining a database. ${ }^{70} \mathrm{With}$ respect to voluntary return, again such things as capacity building are offered, informed by a sensitivity towards the plight of the migrant combined with the desire to preserve 'the integrity of regular migration structures and asylum procedures' ${ }^{71}$

The most eye-catching work, however, is done in relation to border management, as it is here that IOM most overtly assists governments in securing their borders. ${ }^{72}$ IOM engages in border management assessments, evaluating the practices and regulatory frameworks of states in managing entry into and exit from the country concerned. IOM helps to build capacity in border management: institutional, human, and operational capacity. Its African hub (the African Capacity Building Centre), established in 2009, has already trained more than 3,500 individuals. The IOM also engages in what it refers to as identity management, helping states to assess and improve the security of passports and similar instruments. IOM engages in data collection on behalf of its member states, and also occupies itself with migration smuggling and humanitarian border

\footnotetext{
${ }^{66}$ www.iom.int/labour-migration (accessed 16 June 2016).

${ }^{67} \mathrm{Ibid}$

${ }^{68}$ Ibid.

${ }^{69}$ Reportedly, the IOM regularly applies for grants from local governments for specific trafficking projects, competing with NGOs, universities, and both for-profit and non-profit organizations. Among those issuing grants is the US Department of State through its G/TIP office, the office dealing with trafficking in persons. See S. Engle Merry, The Seductions of Quantification: Measuring Human Rights, Gender Violence, and Sex Trafficking (2016), 132.

${ }^{70}$ www.iom.int/counter-trafficking (accessed 16 June 2016).

${ }^{71}$ www.iom.int/assisted-voluntary-return-and-reintegration (accessed 16 June 2016).

${ }^{72}$ www.iom.int/immigration-and-border-management (accessed 28 June 2016).
} 
management. Finally, it aims to help in facilitating migration by providing 'tailored operational assistance' to the migration and consular departments of states. Here it provides 'cross-cutting services', which may include such things as health checks, visa application tracking, skills and language testing, interview facilitation, and verification services. In short, under this heading, IOM essentially provides some or all of the tasks usually associated with member state migration or consular departments, and does so 'on a non-profit basis' ${ }^{73}$ The services are thought to benefit both the migrant and the government concerned, and many of them have been among the IOM's tasks right from the start: ICEM already provided migration services such as selecting, screening and processing migrants in the 1950 s. $^{74}$

\section{The IOM at work}

It is, perhaps, in the nature of the IOM's work on immigration and border management that most of it takes place far from the public view: there is, after all, thought to be a strong connection between migration and national security, all the more so with leading politicians in Europe and elsewhere advocating the building of walls to keep foreigners out. Sometimes, however, snippets of information come to the surface. The IOM itself has published reports on some of its activities or, alternatively, advertised some of its services (the difference is not always easy to tell). Thus, its Armenia office highlights a role for IOM border management at its airports and other border crossings, ${ }^{75}$ while a big chunk of what the local offices in western countries such as the Netherlands or Finland do, consists of facilitating voluntary repatriation. ${ }^{76}$ Most intriguing is also the central focus, or so it seems, of the Danish office, established relatively recently in 2009. Its main task seems to be to offer innovative solutions to migration-related challenges, and these are enumerated as having to do with 'integration, radicalization, discrimination and xenophobia, labour migration, migration and development, counter-trafficking, assisted voluntary return (AVR) of vulnerable migrants and resettlement'. ${ }^{77}$ And it seems that sometimes IOM officials are under instructions not to be overly forthcoming about advertising information about asylum procedures. ${ }^{78}$

The IOM sometimes makes the headlines, e.g., when in the aftermath of the 2001 Tampa affair, its role in providing migration services to Australia was highlighted. The Tampa affair, as will be recalled, involved the refusal of Australia to allow asylum seekers aboard the Norwegian registered ship MV Tampa to enter Australia's territorial waters. The publicity surrounding the affair revealed that Australia pays Indonesia to intercept asylum seekers before they can reach Australia, and that those who are returned to Australia are kept 'in the custody' of the IOM, ${ }^{79}$ apparently at considerable cost: between 2002 and 2005, the IOM's offshore processing centres reportedly cost Australia's taxpayers close to AUS\$120 million. ${ }^{80}$

\footnotetext{
${ }^{73} \mathrm{http}: / /$ www.iom.int/facilitating-migration (accessed on 28 June 2016).

${ }^{74}$ See Ducasse-Rogier, supra note 53, at 29.

${ }^{75}$ See Expansion of Advanced Border Control and Management Technologies in Armenia (2008), available at publications. iom.int/books/expansion-advanced-border-control-and-management-technologies-armenia (accessed 28 June 2016).

${ }^{76}$ www.iom-nederland.nl/en/voluntary-return (accessed 28 June 2016); www.iom.fi/AVRR (accessed 28 June 2016). Intriguingly, both suggest the possibility of financial support for repatriation, including flight tickets and possible cash assistance.

${ }^{77}$ www.iom.int/countries/denmark (accessed 28 June 2016).

${ }^{78}$ See M. Dembour and M. Martin, 'The French Calaisis: Transit Zone or Dead End?', in M. Dembour and T. Kelly (eds.), Are Human Rights for Migrants? Critical Reflections on the Status of Irregular Migrants in Europe and the United States (2011), 123 , at 138. In the same spirit, Guild et al. suggest that local IOM offices reliant on funding from local governments 'may not be as careful ... as head office' about upholding the principle that forced expulsion is wrong. See Guild et al., supra note 59 , at 13 .

${ }^{79}$ See T. Penovic and A. Dastyari, 'Boatloads of Incongruity: The Evolution of Australia's Offshore Processing Regime', (2007) 13 Australian Journal of Human Rights 33, at 35.

${ }^{80} \mathrm{Ibid}$., at 52 . And this still says nothing about the human costs, which can be considerable: IOM camp conditions may be dismal, and the IOM is sometimes accused of not paying attention: ibid., at 43-4.
} 
It would be grossly unfair to claim that the IOM does not have a humanitarian mission, and some of its work clearly oozes a humanitarian spirit. One example is that it drafted a set of International Standards on Immigration Detention and Non-Custodial Measures, designed for further discussion in the UN system, in 2011 - these Standards are explicitly based on prevailing human rights norms, including the case law of the European Court and Inter-American Court of Human Rights. ${ }^{81}$ Another is, that it is generally well-regarded for its work following natural disasters, such as the Haiti earthquake of $2010 .{ }^{82}$

However, it is also clear that some of its work approximates the sort of work normally engaged in by state authorities: the IOM develops and utilizes 'techniques and procedures for directing human behavior', in this case the human behaviour of migrants. ${ }^{83}$ Indeed, it is perhaps especially humanitarian work that lends itself to exercises of 'governmentality', which would suggest that earlier entities such as the United Nations Relief and Rehabilitation Administration (UNRRA) ${ }^{84}$ and more current ones such as the UNHCR, the WHO or the ILO could fruitfully be analysed in such terms. ${ }^{85}$

The IOM engages in a variety of power practices. For one thing, the border management practices it sets up in a number of member states will come to affect the long-term practices of those states. But there is more to it than just that. Like many organizations, the IOM produces handbooks and sets of 'best practices' in its sphere of operations. One of its better-known products is the Handbook on Performance Indicators for Counter-Trafficking Projects (2008) which, as its title suggests, presents a ready-to-use and very detailed model for counter-trafficking projects. Thus, states are assessed on whether they have ratified relevant UN treaties and enacted relevant legislation, but also on such things as whether or not there exists a National Plan of Action to combat trafficking, how much of the budget is allocated to anti-trafficking, how many investigations by trained officers take place (both in absolute terms and relative to the total number of investigations), how many trained prosecutors work on trafficking, how many criminal convictions are issued, et cetera. This imprints not just a particular end result (no trafficking), but also how to get there: the criminal route is, it seems, prioritized, and perhaps not so much because of its inherent merits, but because success here is easier to measure than elsewhere. ${ }^{86}$

Much the same is displayed through other products coming out of IOM. One example is the 2012 Handbook on Diasporas, ${ }^{87}$ filled with 'challenges and 'lessons learned', in order to provide policymakers with 'lessons and good practices'. ${ }^{88}$ The IOM Project Handbook teaches its users how to set up migration projects, with built-in space for gender issues, a human rights-based approach, and environmental sustainability as well as proper financial reporting and management -

\footnotetext{
${ }^{81}$ The Standards are available at www.ohchr.org/Documents/Issues/Detention/DraftBasicPrinciples/IOM3.pdf (accessed 4 November 2017).

${ }^{82}$ See, e.g., Bradley, supra note 37.

${ }^{83}$ The words are Foucault's, as cited in N. Rose, P. O' Malley and M. Valverde, 'Governmentality', (2006) 2 Annual Review of Law and Social Science 83, at 83.

${ }^{84}$ The involvement with UNRRA of Francis Sayre, one of the founding fathers of international organizations functionalism, suggests tantalizing avenues for exploration. On Sayre's role generally, see Klabbers, supra note 4, at 41-8. Sayre's work for UNRRA is documented in his autobiography: see F. B. Sayre, Glad Adventure (1957).

${ }^{85} \mathrm{~A}$ similar intuition underlies S. Legg, “The Life of Individuals as well as of Nations”: International Law and the League of Nations’ Anti-Trafficking Governmentalities', (2012) 25 LJIL 647.

${ }^{86}$ Much the same characterized the UN's administration of East Timor, where human rights (conceptualized in terms of individual incidents and such things as convictions for violations) took priority over the far more difficult and sprawling task of nation-building. See briefly J. Klabbers, 'Redemption Song: Human Rights Versus Community-building in East Timor', (2003) 16 LJIL 367.

${ }^{87}$ See Developing a Road Map for Engaging Diasporas in Development: A Handbook for Policymakers and Practitioners in Home and Host Countries (2012), accessible at publications.iom.int/system/files/pdf/diaspora_handbook_en_for_web_28may2013.pdf (accessed 29 April 2019).

${ }^{88}$ Ibid., at 14 .
} 
therewith reflecting a particular view on what a well-managed migration project should look like and the things that ought to be prioritized. ${ }^{89}$

Some of these products cater rather more to the governmental side of things than to the migrant perspective - an obvious example is the Passport Examination Procedure Manual..$^{90}$ At the same time, sometimes the organization has little choice. A brief passage in the lengthy Emergency Manual is telling, ${ }^{91}$ reminding IOM staff that different donors may have different requirements with respect to issues such as project modification - but quite possibly a number of other issues as well. Obviously, those different requirements need to be respected, lest the donors withdraw their support.

The annual reports on Immigration and Border Management also suggest a direct influence on what member states should be doing. The Border and Identity Solutions unit, e.g., helps assess the technical needs of member states and provides expert advice as well as training and human resources development. ${ }^{92}$ As a result, whatever the IOM says becomes influential: it is the IOM's definition of 'technical needs' that comes to prevail; it is the training provided by IOM which dictates how states end up operating. This further suggests the reflexive nature of much of the IOM's work: insights gained through tasks carried out for member states can be systematized and generalized in Handbooks and Manuals, and fed back to the member states, creating a continuous loop of mutual direction and influence.

\subsection{The IOM and the ideology of functionalism}

The intuition underlying this article is that the unique set-up of the IOM, operating on a private market but endowed with privileges and immunities and the legitimacy derived from its status as international organization, provides insights into the law of international organizations. Observers agree that the IOM is an international organization, a conviction further clinched by the elevation of the IOM to the status of one of the 'specialized agencies' of the UN in 2016. As an international organization, it stands to reason to assess its work and functioning in light of the law of international organizations and its underlying theory. Yet, international organizations law is in a considerable state of theoretical confusion.

On the one hand, both international lawyers and integration theorists have figured out a long time ago that the international civil service can exercise power over member states, simply by virtue of being able to prepare and set the agenda and related activities. ${ }^{93}$ This particular picture has been strengthened in more recent years by lawyers suggesting that the domestic polities of member states have often been re-made along the lines of images suggested by international organizations. This is perhaps most obviously the case with financial institutions such as the International Monetary Fund and the World Bank, which through the medium of conditionality can, effectively, tell member states what to do (this is a lot easier to do with poor member states than with rich ones, though $\left.{ }^{94}\right)$. Something similar, if more subtle, has, however, also been

\footnotetext{
${ }^{89}$ See IOM Project Handbook (2011), available at publications.iom.int/es/system/files/pdf/iom_project_handbook_6feb2012. pdf (accessed 29 April 2019).

${ }^{90}$ See Passport Examination Procedure Manual (2007), available at cb4ibm.iom.int/ibm/index.php/2012-06-13-02-09-37/ publications-and-training-manuals/passport-examination-procedure-manual (accessed 29 April 2019).

${ }^{91}$ The Emergency Manual is set up as an app, or a collection of linked chapters separately navigable on the internet and on smartphones: emergencymanual.iom.int/ (accessed 5 September 2017).

${ }^{92}$ See Immigration and Border Management Annual Review 2012, supra note 27, at 8.

${ }^{93}$ One classic formulation is by E. B. Haas, Beyond the Nation-State (1964); for a more recent elaboration, see J. Mathiason, Invisible Governance: International Secretariats in Global Politics (2007).

${ }^{94}$ It has been observed that especially during the 1990s, the IMF itself was dancing to the tune of the US Treasury, which complicates causality: US influences IMF which, in turn, influences, say, Burundi. For the argument, with considerable empirical substantiation, see R. W. Stone, Controlling Institutions: International Organizations and the Global Economy (2011).
} 
suggested with respect to the Permanent Mandates Commission of the League of Nations ${ }^{95}$ as well as organizations generally. ${ }^{96}$

On the other hand, there is also a general understanding that international organizations are created predominantly with a view to performing functions assigned to them by their member states. Again, one finds this picture both among (international) lawyers and social scientists. In fact, this is the dominant theoretical vantage point, even if rarely recognized as such. ${ }^{97}$ The social scientists often analyse international organizations in terms of delegation theory (or principal/agent theory). ${ }^{98}$ Lawyers speak of functionalism, ${ }^{99}$ by which they mean that as a point of departure international organizations are assigned functions, with the law being geared towards facilitating and protecting the performance of those functions.

Either way, the two perspectives (vehicle for members states versus institutional autonomy) are usually considered not to be incompatible, and their compatibility is usually given a temporal sequence - indeed it is precisely here that the brilliance of functionalism resides, tapping both into the idea that organizations are mere vehicles for their member states, yet at their best when operating with some autonomy. On such a reading, international organizations start as functional agencies exercising delegated powers, assisted by a secretariat which, increasingly, comes to dominate, as the secretariat is the institutional memory of the organization, while member state representatives tend to come and go. ${ }^{100}$

It is here also that the ideological working of functionalism becomes visible. ${ }^{101}$ Functionalism notes that states delegate functions and powers, and tend to do so for the common good. These functions and powers, moreover, are assumed to be non-political. Against such a background, all semi-permanent forms of co-operation must be embraced, sponsored, and facilitated, no matter how nefarious their function may be. Functionalism has little explanatory power; as a theory on what organizations do and how they work it can explain some broad outlines, but little detail: it can explain, e.g., why organizations can be exempt from taxation, but it can never explain the precise levels of tax exemptions - for somehow politics inevitably creeps back in, e.g., in the form of negotiations on the precise level of those tax exemptions. Moreover, the scope of functionalism as an explanatory theory is by definition limited to relations between organizations and their member states; third parties are not involved, yet it is a common feature of the work of organizations that it affects third parties. ${ }^{102}$

But what functionalism lacks in explanatory power, it makes up for in terms of normative appeal, and as an idea, it helps to legitimate the exercise of political power and influence, in this

\footnotetext{
${ }^{95}$ See S. Pedersen, The Guardians: The League of Nations and the Crisis of Empire (2015).

${ }^{96}$ See G. F. Sinclair, 'State Formation, Liberal Reform and the Growth of International Organizations', (2015) 26 EJIL 445; G. F. Sinclair, To Reform the World: International Organizationsand the Making of Modern States (2017); M. Fahkri, Sugar and the Making of International Trade Law (2014).

${ }^{97}$ See Klabbers, supra note 4. As Hirschman has observed, sometimes propositions seem so obvious 'that they are never fully or systematically articulated.' See A. O. Hirschman, The Passions and the Interests (1977), 69.

${ }^{98}$ The seminal volume is Hawkins et al. (eds.), Delegation and Agency (2006).

${ }^{99}$ So do social scientists, but they tend to mean something else by the term. In relation to international organizations, functionalism usually refers to the idea that once forms of co-operation around specific functions are established, they will beget further co-operation. The standard reference is D. Mitrany, A Working Peace System (1943). In a nutshell, lawyers ask themselves how co-operation is structured, while political science functionalists ask how co-operation can be stimulated. Still, often the two meanings are confused; a telling example is A. A. Fatouros, 'On the Hegemonic Role of International Functional Organization', (1980) 2 German Yearbook of International Law 9.

${ }^{100}$ Some such narrative underlies T. Johnson, Organizational Progeny: Why Governments are Losing Control Over the Proliferating Structures of Global Governance (2014).

${ }^{101}$ See further J. Klabbers, 'What Role for International Organizations in the Promotion of Community Interests? Reflections on the Ideology of Functionalism', in E. Benvenisti and G. Nolte (eds.), The Community Interest Across International Law (2018), 86.

${ }^{102}$ See J. Klabbers, 'Theorising International Organisations', in Orford and Hoffmann, supra note 50, at 618.
} 
case the influence exercised by the IOM over its member states. In their insightful account of global governance, Avant, Finnemore and Sell distinguish five bases of authority of global governors. These may derive authority from an institution (e.g., the managing director of the International Monetary Fund); authority may derive from delegation; it may stem from expertise; it may originate in being seen as a principled actor (this may apply to individuals but also to nongovernmental organizations); and authority may be capacity-based. This latter form remains a bit opaque, and Avant et al. concede it is difficult to think of concrete examples, but capacity-based authority may owe something to having been given a specific task or, in words resonating with international organizations lawyers, a function. ${ }^{103}$

One possible ramification is that capacity-based authority may stem from legal form. In a different context, a law on fiduciary duties, e.g., may have the effect that an individual may get to exercise authority over someone else; may in the process perform a number of legal acts associated with the position and, importantly, may also be seen as having great legitimacy (however defined really), and this stems in part from the very existence of the position. There is a general assumption that those entrusted with fiduciary obligations work for the good of those entrusted to their care - loyalty is generally seen as a key element. In other words, there is a strong ideological component at work, informing and steering the formal legal rules on fiduciary obligations. ${ }^{104}$ The formal holder of such obligations may derive authority from his or her expertise, but will also derive some authority from the very position of holding fiduciary obligations; the position is generally associated with the greater good (however precisely employed) and rests on a number of assumptions of what makes for a proper holder of the position. It is possible, of course, to forfeit this authority in specific case, e.g., by performing badly, or ignoring legal limitations, but the underlying assumption will remain forceful: fiduciary obligations are regulated by law, and the holders thereof appointed by law, precisely as an expression of the good.

Much the same applies to the functionalist law on international organizations. In this branch of the law, functionalism functions as an ideology, a set of beliefs that may or may not be true or false, but at least serves the practical needs of the people who hold it. ${ }^{105}$ The idea that international organizations can do no wrong is deeply engrained, and it is no coincidence that the law tends to suggest that where international organizations actually do wrong, often enough their member states are or should be to blame, ${ }^{106}$ or they are not 'really' organizations. ${ }^{107}$ Functionalism stimulates all forms of international joint ventures between states, and therewith helps to legitimize them. ${ }^{108}$ The setting up of a river commission in early twentieth century China could easily have been seen as a collective exercise in imperialism; calling the same river commission an

${ }^{103}$ See D. D. Avant, M. Finnemore and S. K. Sell, 'Who Governs the Globe?', in Avant et al. (eds.), Who Governs the Globe? (2010), 1, at 11-14.

${ }^{104}$ See, e.g., L. Smith, 'Fiduciary Relationships: Ensuring the Loyal Exercise of Judgment on Behalf of Another', (2014) 130 Law Quarterly Review 608. On the relevance of loyalty in this context see also G. Fletcher, 'Loyalty', in D. Patterson (ed.), A Companion to Philosophy of Law and Legal Theory (1996), 524.

${ }^{105}$ This is a broad and loose definition, but sufficient for present purposes, derived from M. Goldie, 'Ideology', in T. Ball, J. Farr and R. L. Hanson (eds.), Political Innovation and Conceptual Change (1989), 266, at 267. A useful overview of the various meanings that the term ideology can be given in S. Marks, The Riddle of All Constitutions: International Law, Democracy, and the Critique of Ideology (2000), 8, while the role of ideology in judging is discussed at length in D. Kennedy, A Critique of Adjudication: (Fin de Siècle) (1997).

${ }^{106}$ See, e.g., M. Hirsch, The Responsibility of International Organizations toward Third Parties: Some Basic Principles (1995).

${ }^{107}$ See, e.g., B. Schwartz and E. Leven, 'International Organizations: What Makes Them Work?', (1992) 30 Canadian Yearbook of International Law 165.

${ }^{108} \mathrm{An}$ arguably extreme rendition is the fiduciary version proposed by Criddle and Fox-Decent, which is not cast in explicitly functionalist terms but nonetheless highly compatible. To their minds, the legal competences of international organizations are 'held in trust by international institutions on behalf of humanity. Accordingly, international institutions must exercise their legal power in a manner that serves humanity'. See E. J. Criddle and E. Fox-Decent, Fiduciaries of Humanity: How International Law Constitutes Authority (2016), 288. A related, if more philosophical, approach is developed by C. E. Pavel, Divided Sovereignty: International Institutions and the Limits of State Authority (2015). 
'international organization', however, gives it a strong veneer of respectability, and ends up legitimizing the entity. By the same token, Western military troops patrolling in Afghanistan may be seen as intervention; those same Western military troops doing so as NATO forces, however, seems like legitimate policing.

In this landscape of international agencies exercising delegated tasks yet claiming some autonomy and authority, the IOM occupies a curious place: it is functionalist in a way that does not apply to many other international organizations, taking functionalism to the extreme by providing private services to individual member states (typically doing their 'dirty work') and therewith stretching the theory beyond its breaking point. It has always been viewed as being held 'to a fairly narrow portfolio of service provision by its member states'. ${ }^{109}$ An indication is that it is rarely considered to have a purely humanitarian mission and that its humanitarian credentials do not always meet with the unqualified approval of other humanitarian agencies working in the same field, ${ }^{110}$ despite its general brief to occupy itself with issues related to migration and the fact that it deals with vulnerable humans. ${ }^{111}$ In fact, its Constitution suggests a Janus-faced agency, as seen above: part humanitarian and (bigger) part extension of member states. The message seems clear: the IOM was set up, in part, to do the work of states related to migration. And as the previous sections of this article have sought to demonstrate, this is exactly what the IOM does. By managing migration procedures for states; by advising on airport logistics; by providing advice on passport examinations; by setting out best practices for visa processing; by stimulating the voluntary return of migrants; by running migration processing centres; through all these means the IOM works at the behest of individual member states (rather than, as is usually the case with international organizations, for the member states jointly). These individual states hire the IOM to perform a specific task, in much the same way individuals might hire a plumber or electrician. Or, to offer a more accurate analogy: for a state to enlist the services of the IOM is the equivalent of an individual enlisting a police officer, complete with powers of arrest and similar trappings, rather than a private security guard. This suggests, in turn, that one of the building bricks of the ideology of functionalism is precisely the connection to the private market: the public/private distinction here operates both to ensure that the IOM can act outside public scrutiny, but with all the advantages of being a recognized public actor.

In the theory of international organizations law, all international organizations are set up by their member states to perform certain tasks. ${ }^{112}$ There is, indeed, no alternative: international organizations do not arise spontaneously, nor can they be said to be created 'naturally', or 'organically', or in other, similar manner. They need to be created, and the literature is unanimous that this 'act of creation' ${ }^{113}$ has a functional orientation. Still, some of the classic literature ${ }^{114}$ already mentions some examples of entities set up to protect particular private interests (the safety of some shipping routes, security of commerce in some places) as examples of international organizations, therewith endowing these entities with the legitimacy accompanying the label 'international organization'. ${ }^{115}$ And then there are organizations whose raison d'être resides

\footnotetext{
${ }^{109}$ See Newland, supra note 18 , at 332 .

${ }^{110}$ It has been documented that IOM's conceptualization of 'irregular migration' for instance, was received with some reluctance by both UNHCR and NGOs such as Human Rights Watch. See J. Handmaker and C. Mora, 'Experts: The Mantra of Irregular Migration and the Reproduction of Hierarchies', in Ambrus et al. (eds.), The Role of 'Experts', 263, at 275-7.

${ }^{111}$ Anecdotal, but telling: in March 2016, I attended a small expert meeting on Europe's refugee influx, organized by the EU's Fundamental Rights Agency. Around the table were representatives from several humanitarian agencies and NGOs (UNHCR, Aire, EASO) as well as from several border protection agencies (two national ones, plus the EU's Frontex), but none from the IOM. When I asked the chairperson afterwards, he acknowledged that he had not given much thought to inviting the IOM, but would have probably extended an invitation had the meeting been set up on a larger scale.

${ }^{112}$ See generally Klabbers, supra note 4; and Klabbers, supra note 102.

${ }^{113}$ Indeed, one popular study of the origins of the UN carries this title: see S. C. Schlesinger, Act of Creation: The Founding of the United Nations (2003).

${ }^{114}$ This applies in particular to Sayre, supra note 38.

${ }^{115}$ This legitimacy in turn owes much to the (ostensible) public mission of international organizations, who are typically seen to be working for the common good.
} 
not in any instrumental rationalism, but rather in political rationalities. This has been argued with respect to the Arab League ${ }^{116}$ and the erstwhile Organization of African Unity, ${ }^{117}$ for instance.

Against this background, the IOM stands out as it operates as the extension of its member states. This need not be the result of nefarious intentions - as Susan Pedersen has suggested, 'practices and proclivities' sometimes bump up 'against the aims, claims, and interests of the powers and peoples' involved, 'producing meanings and outcomes no one had intended'. ${ }^{118}$ Even the mere practices of defining migrants, categorizing them, and quantifying things can come to have a profound impact on people's everyday lives. Quantification, as Sally Engle Merry recently put it, is seductive, ${ }^{119}$ and precisely because international organizations are uniquely positioned to gather information from all corners of the globe, they are uniquely placed to create and disseminate information which, in turn, may have real consequences for real people. ${ }^{120}$ And as noted, in particular, the border control practices of the IOM may end up setting standards for others to emulate and imitate.

The delegation literature (of which legal functionalism forms part) tends to think of delegation as uni-directional: it aims to explain how and why states delegate powers and functions to international bodies, ${ }^{121}$ but rarely pays attention to the reverse process: how can it be explained that organizations aim to influence their member states, the very same actors that created them and delegated powers to them to begin with? How is it possible that an international organization such as the IOM ends up telling member states what to do, without having been endowed with the task of doing so?

And indeed, functionalism in international organizations law has no answer. Functionalism is not capable of providing a robust explanation except in those (rare) cases where the international organization has actually been given the power to regulate state behaviour and practices: where the agent comes to control the principal, the principal-agent relationship is distorted. Where the delegate comes to control the delegator, the relationship is distorted. It is this that the IOM case highlights: this most 'functionalist' of international organizations, often acting faithfully in accordance with its member state's wishes, nonetheless presents functionalism with puzzles that the theory is ill-equipped to deal with.

If the facts are not supported by the theory yet the theory remains adhered to, it can only be because of its appeal along other dimensions. This is the case with functionalism in international organizations law: it is kept in place because it is considered normatively attractive, promising, as it does, the 'salvation of mankind'. It cannot explain much, but wouldn't it be nice if the world be organized along functional lines? In doing so, functionalism comes to work as ideology, as a set of beliefs steering human activity, and it is clear that the IOM draws tremendous benefits from this.

Partly these benefits are material, in the form of immunities. The IOM website states, e.g., that standard contracts and purchase orders relating to goods and services contain references to the IOM's immunities, ${ }^{122}$ and those immunities, in turn, stem from its status as an international organization, while immunities of international organizations, in their turn, owe much to the logic of functionalism: the perceived need to facilitate the functioning of international organizations.

\footnotetext{
${ }^{116}$ See M. Barnett and E. Solingen, 'Designed to Fail or Failure of Design? The Origins and Legacy of the Arab League', in A. Acharya and A. I. Johnston (eds.), Crafting Cooperation: Regional International Institutions in Comparative Perspective (2007), 180.

${ }^{117}$ Herbst tellingly claims that the OAU was 'despite its name, devoted to ensuring the division of Africa was viable by strengthening individual states'. See J. Herbst, 'Crafting Regional Cooperation in Africa', in ibid., 129, at 133.

${ }^{118}$ See Pedersen, supra note 95, at 406.

${ }^{119}$ See Engle Merry, supra note 69; see also K. E. Davis et al., Governance by Indicators: Global Power through Quantification and Rankings (2012).

${ }^{120}$ The same point transpires from Sinclair, To Reform the World, supra note 96.

${ }^{121}$ See, e.g., C. Bradley and J. G. Kelley, 'The Concept of International Delegation', (2008) 71 Law and Contemporary Problems 1.

${ }^{122}$ www.iom.int/iom-general-procurement-principles-and-processes (accessed 11 February 2018).
} 
Partly also, the benefits accruing to the IOM are intangible: since all international organizations are associated with the global good, all enjoy a certain legitimacy simply from this association. The ideological nature of functionalism imbues international organizations with a cosmopolitan aura, regardless of what it is they do. Elusive as this may be, its significance for global governance cannot be gainsaid.

\section{Conclusion}

What is special about the IOM is, to some extent, a matter of degree. Other international organizations also perform services for their individual member states, and do so on their request and against a fee. But there are two major differences with other organizations engaged in the provision of services (think of the International Civil Aviation Organization providing airport safety inspections or pilot training). First, their services are politically markedly less controversial than those of the IOM, and secondly, these organizations are not nearly as dependent on market-based funding as the IOM. While operating on markets is not specific to the IOM, what is specific is the extent and degree to which the IOM does so, and the controversial nature of some of these activities. Few will deny that pilots ought to be regularly trained; many might be upset though upon realizing that the IOM operates controversial security functions for individual member states.

This article has demonstrated that the work of the IOM, much of its taking place on a privatized market for migration, is both driven by member states and aims to steer the policies of those same member states through seemingly innocuous means. The IOM influences the policies of states through the production of manuals, collections of best practices, and saves them from unwanted or 'irregular' migration flows. In doing so, this article has also shed some light on two fundamental issues in the law of international organizations, made visible precisely by the IOM's operations: how the state-like technologies and the state-driven work of the IOM affect the underlying functionalist legal theory.

At the same time, the work of the IOM demonstrates that states, while they may remain nominally in control of their international organizations, nonetheless tend to bow to the often superior expertise gathered by functionalist specialists, who influence the policies these states may adopt domestically, and often do so through innocuous means: manuals, sets of best practices, indicators, and the like. This is facilitated precisely by the legal form of international organization and the underlying theory thereof. If it is generally assumed that international organizations will contribute to the 'salvation of mankind' and will help to 'turn swords into plowshares', in the biblical analogy, ${ }^{123}$ then policy prescriptions stemming from those organizations come with a strong aura of legitimacy, regardless of the content of those policy prescriptions. Activities stemming from an international organization can tap into an entire and long-standing, uncontroversial repository of ideas and beliefs about the good they represent. It is not just the expertise of the IOM's officials that gives rise to this authority; it is strengthened in considerable measure by the functionalist approach to the law of international organizations.

\footnotetext{
${ }^{123}$ One of the classic textbooks on international organizations carries this motto in its title: see I. L. Claude Jr., Swords into Plowshares: The Problems and Progress of International Organization, (1959).
}

Cite this article: Klabbers J (2019). Notes on the ideology of international organizations law: The International Organization for Migration, state-making, and the market for migration. Leiden Journal of International Law 32, 383-400. https://doi.org/ $10.1017 /$ S0922156519000165 